\title{
A MÁ LEITURA DA “MOLDURA DA NORMA” DE KELSEN COMO ÁLIBI PARA A DISCRICIONARIEDADE JUDICIAL
}

\author{
THE BAD READING OF THE "FRAME OF THE NORM" OF KELSEN AS \\ AN AL-IBI TO JUDICIAL DISCRETION
}

Bernardo Schmidt Penna ${ }^{\mathrm{I}}$

Henrique Garbellini Carnio ${ }^{\mathrm{II}}$

I Universidade Federal de Rondônia, Porto Velho, RO, Brasil. Doutor em

Direito. E-mail: bernardospenna@bol. com.br

II Faculdade Autônoma de Direito e Universidade Presbiteriana Mackenzie, São Paulo, SP, Brasil. Doutor em Filosofia. E-mail: henriquegarbellini@ uol.com.br

\begin{abstract}
Resumo: O presente estudo tem por objetivo esclarecer o que de fato é a metáfora da "moldura da norma" de Hans Kelsen, uma vez que sua leitura superficial ou até mes-mo tendenciosa pode dar azo a entendimentos equivocados acerca dessa teoria, sobretudo associando-a à discricionariedade judicial. A pesquisa se deu de forma bibliográfica com extensa análise doutrinária bem como jurisprudencial. Orientandose pelo método indutivo, se valerá dos ensinamentos do próprio Kelsen, bem como de alguns de seus pertinentes comentadores. Ao final, pela via do método dedutivo, se concluirá, a partir de uma pequena exposiçáo de julgados dos tribunais pátrios evidenciando o uso indevido da metáfora da moldura na interpretação das normas jurídicas.
\end{abstract}

Palavras-chave: Moldura da norma. Hans Kelsen. Discricionariedade judicial.

\begin{abstract}
This study aims to clarify what actually is the metaphor of the "Frame of the norm" of Hans Kelsen, since its brief reading or even biased could lead to wrong understandings about this theory, particularly linking it to judicial discretion. It will also make use of the teachings of Kelsen, as well as some of its relevant commentators. Finally, it will make a small exhibition of patriotic Courts highlighting the misuse of the frame of the metaphor in the interpretation of legal norms.
\end{abstract}

Keywords: Frame of the norm. Hans Kelsen. Judicial discretion. 


\section{Introduçáo}

O bom juiz nada faz por seu próprio arbitrio, mas se pronuncia segundo as leis e o Direito

(Santo Tomás de Aquino)

To primeiro parágrafo da sua Teoria Pura do Direito, ${ }^{1}$ Hans Kelsen já anuncia que

1 se trata de uma obra de teoria geral do Direito e não da interpretaçáo de normas jurídicas específicas. Indica, assim, que não cuidará de elementos da decisão judicial. Tal enfoque não é desarrazoado e, sim deliberado, como se verá.

Contudo, tornou-se extremamente famoso o capítulo VIII desta obra em que ele trata justamente acerca da interpretação. O que ocorre em paralelo, por obra de uma doutrina e de um Judiciário, em certa medida, pouco qualificados e, por que não dizer, às vezes soberbos, é uma má leitura desse escritos, deturpando-os, sobretudo para que se justifique o uso da discricionariedade.

Tudo parece ter início já em uma má colocação de Kelsen dentro do próprio positivismo. Tido equivocadamente por rasos conhecedores como exegético, uma eventual "abertura" para a "criação" deliberada em sua doutrina, já daria azo a um sério engano. "Se até o Kelsen admite discricionariedade...”. É disso e de outras facetas dessa deturpação que cuidará o presente artigo.

Mesmo que sobre outro prisma, vale o brado de Willis Santiago Guerra Filho e Henrique Garbellini Carnio ${ }^{2}$ proclamando a chegada do momento oportuno para nos livrarmos de certos clichês oriundos de leituras acríticas da obra de Kelsen.

O objetivo do presente artigo é revelar como o mau uso do que Kelsen denominou "moldura da norma” vem servindo como uma espécie de álibi para a justificação do uso indiscriminado da discricionariedade. Orientando-se pelo método indutivo, se valerá dos ensinamentos do próprio Kelsen, bem como de alguns de seus pertinentes comentadores.

Ao final, pela via do método dedutivo, se concluirá, a partir de uma pequena exposição de julgados dos tribunais pátrios evidenciando o uso indevido da metáfora da moldura na interpretação das normas jurídicas.

A análise de tal circunstância demonstra-se importante, uma vez que a prática ora evidenciada redunda em algo nocivo no que refere à interpretação judicial, uma vez que dá azo à deletéria discricionariedade.

A pesquisa é de natureza bibliográfica e se valeu da análise de extenso material desenvolvido pelo próprio Kelsen, bem como por demais juristas, além do uso de julgados.

Embora se depare com o fato de que Kelsen modificou alguns de seus entendimentos desde a primeira edição da Teoria Pura do Direito, se valerá neste estudo das liçóes do autor

1 Vale já de antemão expor uma crítica à tradução latina do título da obra máxima de Kelsen Reine Rechtslehre. Devido à extensão pretendida pelo mestre de Viena de abarcar a ciência do Direito como um todo, o uso do vocábulo para a tradução em língua latina deveria ser 'Doutrina' em vez de 'Teoria'. Como supedâneo: Theo'rie (f.: die) - teoria (p. 586); e 'Lehre (f.: die) - (Unterricht; m.: der) ensino; (Theorie; f.: die) teoria; (Wissenschaft; f.: die) ciência (p. 503) Langenscheidt Taschenwörterbuch. München: Editora Langenscheidt, 2001. Alguns autores, mesmo que latinos, como o italiano Mario Losano, assim a tratam (In Sistema e Estrutura no Direito. Vol 2 o século XX. Tradução Luca Lamberti. São Paulo: Martins Fontes, 2010, passim). No Brasil, por todos, Willis Santiago Guerra Filho e Henrique Garbellini Carnio.

2 In Teoria da Ciência Jurídica. 2.ed. São Paulo: Saraiva, 2009, p.160. 
austríaco já a partir da segunda edição da referida obra (1960), não se valendo nas análises ora apresentadas, por evidente, apenas desta.

\section{A interpretação segundo Kelsen}

Leviano se dizer, embora lugar comum, que Kelsen não se importou com a interpretação das normas jurídicas. É verdade que não se dedicou a descrevê-la ou explicá-la com profundidade, mas isso foi deliberado e por fundadas razóes. Vale, de antemão, desfazer-se tal premissa equivocada.

Kelsen, ao contrario de como costuma se acreditar, não abandona em sua Doutrina Pura do Direito a interpretação de forma geral. Ele deixa de trabalhar a decisão judicial, especificamente. Mas isso não redunda em uma desistência ou negligência no tratamento da interpretação, que pode ser vista em diversos pontos da obra, com um capítulo específico, inclusive.

Com Juliana Neuenschwander Magalhães temos que Kelsen renunciou em enfrentar essa questão limite da Ciência do Direito sob o custo de manter intactos os pressupostos metodológicos dela. Ele sabia, segundo a autora mineira, "que pela janela da interpretação jurídica 'reentravam' no Direito aqueles elementos que ele havia cuidado de eliminar na construção de um objeto 'puro". ${ }^{3}$

Seria, dessa forma, um "abandono estratégico" esse desprezo ou recusa em aprofundar o tema (da decisão judicial mais propriamente), o que não o torna inexistente nem muito menos invisível ou não passível de apreciação, como ora se propóe.

Kelsen, já no início de sua Teoria Pura do Direito, ao analisar os juízos de valor objetivos e subjetivos em paralelo à função do conhecimento, faz a ressalva de que:

Os predicados "objetivo" e "subjetivo" se referem aos valores expressos e não ao juízo como função do conhecimento. Como função do conhecimento tem um juízo de ser sempre objetivo, isto é, tem de formular-se independentemente do desejo e da vontade do sujeito judicante. ${ }^{4}$

Adiante, faz uma comparação entre um juízo moral e um juízo jurídico (objetivo) para ilustrar a diferença quanto ao subjetivismo do intérprete:

A resposta à questão de saber se, de acordo com a moral cristá, é bom amar o inimigo, e o juízo de valor que daí resulta, pode e deve dar-se se ter em conta se aquele que tem de responder e formular o juízo de valor aprova ou desaprova o amor aos inimigos. A resposta à questáo de saber se, de acordo com o Direito vigente, um assassino deve ser punido com a pena capital, e, assim, se a pena de morte para o homicida é valiosa de acordo com esse Direito, pode e deve verificar-se sem ter em conta se aquele que deve dar a resposta aprova ou desaprova a pena de morte. ${ }^{5}$

Kelsen já havia aduzido, considerando os juízos pessoais sobre as coisas e a afirmação de que algo é "bom" ou "mau" separando o que chamou de função do conhecimento e função dos componentes emocionais, que isso:

3 Sobre a Interpretação Jurídica. Revista de Direito Comparado. Vol 3. Belo Horizonte: Faculdade de Direito da UFMG, 1999, p. 429.

4 In Teoria Pura do Direito. Tradução João Baptista Machado. 6.ed. São Paulo: Martins Fontes, 2003, p. 22.

5 Idem, p. 23. 
Constitui apenas a imediata expressão do seu desejo desse algo (ou do seu contrário), essa afirmação não é um "juízo" de valor, visto não corresponder a uma função do conhecimento mas a uma função dos componentes emocionais da consciência. ${ }^{6}$

Mas é no capítulo VIII que é reservado espaço específico, embora curto, à interpretação. Kelsen começa a explanação conceituando a interpretação como "uma operação mental que acompanha o processo de aplicação do Direito no seu progredir de um escaláo superior para um escalão inferior". ${ }^{7}$

A partir disso, divide em interpretação da lei, da Constituição e aquela feita por indivíduos, subdividindo, ainda, a interpretação em duas espécies ${ }^{8}$ interpretaçáo do órgão aplicador e interpretação por não aplicadores, notadamente, particulares e, sobretudo, a ciência jurídica. ${ }^{9}$

A interpretação autêntica (promovida pelos órgãos aplicadores do Direito) é entendida por Kelsen como um "ato de vontade", ${ }^{10}$ o que também se conservaria como marca distintiva dessas interpretaçôes.

Além desta divisão e, por que não dizer, a partir dela, Kelsen também a efetua a cisão da interpretação como ato de vontade e ato de conhecimento. Lênio Streck ${ }^{11}$ aduz que esta divisão é proveniente do que, para Kelsen, seria o problema da interpretação do direito mais semântico do que sintático, enfatizando, assim, a semântica. ${ }^{12}$

Henrique Garbellini Carnio, em artigo dedicado ao tema, ensina que "do ponto de vista jurídico não se destaca nunca como objeto da "vontade" uma representação, mas sempre fenômenos de ordem exterior, substratos de fato." ${ }^{13} \mathrm{E}$ continua consignando que:

O que realmente interessa à jurisprudência é, com efeito, encontrar a conexão entre os substratos exteriores do fato e os sujeitos. O que importa ao jurídico e deve ser colocado em termos de problematicidade é o de se um fato exterior há sido "querido" ou não pelo sujeito. ${ }^{14}$

O fato de ser considerada por kelsen como ato de vontade é determinante para a análise aqui proposta sobre a interpretação. Garbellini Carnio prossegue aduzindo que:

Kelsen conclusivamente constata que o conceito de vontade em sentido ético-jurídico tem um significado totalmente distinto do que pode ter, qualquer que o seja, o conceito

$6 \quad$ Idem, p. 21.

7 Idem, p. 387.

8 Idem, p. 388.

9 À interpretação promovida pelos órgãos aplicadores, Kelsen dá também o nome de autêntica, ao passo que aquela realizada pelos particulares ou pela ciência jurídica, seria a inautêntica. Idem, p. 394-395.

10 Idem, p. 249.

11 STRECK, Lênio. Verdade e Consenso - Constituição, hermenêutica e teorias discursivas. 5.ed. São Paulo: saraiva, 2014, p. 35.

12 Semântica, sintaxe e pragmática são dimensôes da semiótica. Conforme GUERRA FILHO e GARBELLINI CARNIO temos que "Nos estudos semióticos é possível distinguir três dimensôes, subordinadas e interdependentes mutuamente, identificadas a partir dos três diferentes modos como podem relacionar-se com os signos, os objetos a que se referem e os seus intérpretes ou usuários. Na sintática, estuda-se a relação dos signos entre si (...) na semântica, estuda-se a relação deles com os objetos a que se aplicam. Na pragmática o tema é a relação dos signos com os usuários e vice-versa. In Teoria da Ciência Jurídica. 2.ed. São Paulo: Saraiva, 2009 , p. 162 , nota 283.

13 In O Pensamento Kelseniano e o Conceito de Vontade no direito Privado. Revista de Direito Privado. Vol 51 - Jul - Set, 2012. RT on line. Consulta em 16-03-16.

14 Idem. 
psicológico de vontade, o que entranha um processo anímico efetivo e que por vontade em sentido ético-jurídico não pode se entender um ato psíquico de nenhuma classe, senão uma construção erigida com vistas à imputação, exclusivamente. ${ }^{15}$

Nessa linha de intelecção, para Samuel Moreira Gouveia, ${ }^{16}$ a imprecisa relação entre interpretaçáo e norma na doutrina kelseniana se afigura ainda como um imediato obstáculo. Ele cita Guastini para informar que interpretar é atribuir um significado a um significante e, dessa forma, a norma jurídica deveria ser o ponto de chegada da interpretaçáo e não seu ponto de partida. O texto seria o objeto de interpretação e a norma seu produto.

Em outra obra, o jurista austríaco, ainda que de maneira discreta e sucinta, trata da interpretação também com relação à linguística, aduzindo que "uma lei é expressa em palavras que muitas vezes são ambíguas e podem ser interpretadas pelos órgãos aplicadores da lei de um modo não pretendido pelo legislador." ${ }^{17}$

É necessário notar, todavia, que não há qualquer referência a uma interpretação totalmente livre e sim interpretação não conforme a uma (inexistente como ele mesmo assevera) "vontade do legislador".

Importante consignar ainda, valendo-se das palavras de Gabriel Nogueira Dias comentando a obra de Kelsen, que pode-se defender que este entende que "o(s) ordenamentos(s) jurídico(s) deve(m) ser analisado(s) e descrito(s) exclusivamente em relação a si mesmo(s) e sem recurso a outras instâncias, metafísicas ou fáticas." 18

Tal afirmação, por óbvio, deve se estender à interpretaçáo, traduzindo, claramente, a indisposição de Kelsen em aceitar “intrusões” no âmbito do ordenamento jurídico.

\subsection{A 'moldura da norma' de Kelsen}

Prossegue o autor austríaco em sua obra maior, agora para se referir expressamente ao que chamou de "moldura da norma", aduzindo que a relação de determinação entre aqueles escalóes não é completa, razão pela qual:

Tem sempre de ficar uma margem, ora maior ora menor, de livre apreciação, de tal forma que a norma do escaláo superior tem sempre, em relação ao ato de produção normativa ou de execução que a aplica, o caráter de um quadro ou moldura a preencher esse ato. ${ }^{19}$

Juliana Neuenschwander Magalhães evidencia que, para o jurista austríaco, "a ciência do direito pode ocupar-se da interpretaçáo jurídica apenas na medida em que esta se presta a traçar a "moldura" das interpretaçôes possíveis de uma norma jurídica." ${ }^{20}$

Kelsen avalia que a norma pode possuir várias significaçóes verbais e que o ato jurídico que efetiva ou executa a norma pode se referir a qualquer desses significados, asseverando que:

15 Idem.

16 In Kelsen e a Interpretação Humpty Dumpty. (no prelo)

17 O Que é Justiça. Trad. Luis Carlos Borges. 3.ed. São Paulo: Martins Fontes, 2001, p. 211.

18 In Positivismo Jurídico e a Teoria Geral do Direito: na obra de Hans Kelsen. São Paulo: Editora revista dos Triunais, 2010, p. 130.

19 In Teoria Pura do Direito. Tradução João Baptista Machado. 6.ed. São Paulo: Martins Fontes, 2003, p. 388.

20 Sobre a Interpretação Jurídica. Revista de Direito Comparado. Vol 3. Belo Horizonte: Faculdade de Direito da UFMG, 1999, p.430. 
O Direito a aplicar forma, em todas as hipóteses, uma moldura dentro da qual existem várias possibilidades de aplicação, pelo que é conforme ao Direito todo ato que se mantenha dentro deste quadro ou moldura em qualquer sentido possível. ${ }^{21}$

André Ramos Tavares sintetiza de maneira percuciente a moldura de Kelsen, considerando-a "nada mais do que o plexo de possibilidades semânticas da norma."22

Mesmo considerando que dizer que uma sentença fundada na lei significa que ela está contida na moldura da lei, sendo uma de suas várias possibilidades, o jurista austríaco reconhece que não há método capaz de definir qual dessas possibilidades seria a correta. ${ }^{23}$

É imperioso se notar que Kelsen não dá ao intérprete poder criativo ao largo da própria moldura antes oferecida. Mesmo em caminho oposto ao de Dworkin ${ }^{24}$, existem limites e estes limites deverão ser estritamente observados pelo intérprete autêntico.

Uma leitura tendenciosa facilmente pode levar à conclusão que se trata de uma livre criação do intérprete chancelada por um positivista normativista da envergadura de Hans Kelsen. Abboud, Garbellini Carnio e Oliveira chamam atenção para o fato de que o positivismo normativista, que teve em Kelsen seu maior expoente:

Opera uma análise semântico-sintática do direito. Desse modo, reconhece o problema dos múltiplos significados que emanam dos conceitos que compóem o direito e problematiza a relação desses conceitos com os objetos que compóem o "mundo jurídico". ${ }^{25}$

Para Marcelo Cattoni de Oliveira, analisando a metáfora da moldura, tem-se que:

O direito a aplicar forma uma moldura ou quadro dentro do qual existem várias possibilidades de aplicação, pelo que é conforme ao Direito todo ato que se mantenha dentro desse quadro ou moldura, que preencha essa moldura em qualquer sentido possível. ${ }^{26}$

E emenda o autor mineiro:

Se, em princípio, por interpretação se entende a fixação por via cognoscitiva do sentido do objeto a interpretar, o resultado de uma interpretação jurídica somente pode ser a fixação da moldura que representa o Direito a interpretar e, consequentemente, o conhecimento das várias possibilidades que dentro dessa moldura existem. ${ }^{27}$

21 In Teoria Pura do Direito. Tradução João Baptista Machado. 6.ed. São Paulo: Martins Fontes, 2003, p. 390.

22 A Interpretação Jurídica em Hart e Kelsen:uma postura (anti) realista. In DIMOULIS, Dimitri. Et al (coord) Teoria do Direito Neoconstitucional - superação ou reconstrução do positivismo juírico? São Paulo: Método, 2008, p.148.

23 In Teoria Pura do Direito. Tradução Joáo Baptista Machado. 6.ed. Sáo Paulo: Martins Fontes, 2003, p. 391.

24 Orlando Faccini Neto adverte que a resposta correta de Dworkin "deve ser entendida como uma metáfora, que decorre de uma simbiose entre a teoria integrativa, sustentada por Dworkin,e a fenomenologia hermenêutica, que abarca a hermenêutica filosófica." In Elementos de Uma Teoria da Decisão Judicial - Hermenêutica, Constituição e respostas corretas em Direito. Porto Alegre, 2011, p. 25.

25 ABBOUD, Georges; CARNIO, Henrique Garbellini; OLIVEIRA, Rafael Tomaz de. Introdução à Teoria e à filosofia do Direito. São Paulo: Editora Revista dos Tribunais, 2013, p. 206.

26 Interpretação Como Ato de Conhecimento e Interpretação como Ato de Vontade: a tese kelseniana da interpretação autêntica. Jurisdição e Hermenêutica Constitucional. CATTONI DE OLIVEIRA, Marcelo (org.). Belo Horizonte: Mandamentos, 2004, p. 138.

27 Idem, p. 138 
No que se refere ainda à criação do Direito, Kelsen informa que a vinculação do legislador é bem menor que a do julgador e que este último é também "relativamente livre" 28 para criar Direito. Admite ser um processo volitivo, inclusive, o preenchimento da moldura da norma.

Ocorre, no entanto, uma significativa ressalva feita pelo jurista austríaco e que serve como chave para o que se pretende demonstrar neste estudo. Assim ele se manifesta:

Na medida em que, na aplicação da lei, para além da necessária fixação da moldura dentro da qual se tem de manter o ato a pôr, possa ter ainda lugar uma atividade cognoscitiva do órgão aplicador do Direito, não se tratará de um conhecimento do Direito positivo, mas de outras normas que, aqui, no processo da criação jurídica, podem ter a sua incidência: normas de Moral, normas de Justiça, juízos de valor sociais que costumamos designar por expressóes correntes como bem comum, interesse do Estado, progresso etc. Do ponto de vista do Direito positivo, nada se pode dizer sobre a sua validade e verificabilidade. ${ }^{29}$

Dessa forma, não fica distante a conclusão de que, embora Kelsen defenda um certo grau de discricionariedade, impóe também um limite. Com efeito, limites claros orientados pela própria norma. Assim, não há qualquer "poder criativo" desvinculado do próprio Direito. Não admite juízos externos e nem mesmo, evidentemente, juízos pessoais (subjetivos) do julgador.

O mestre de Viena sofre críticas quanto ao seu distanciamento das teorias da interpretação ou até mesmo uma intolerância, ${ }^{30}$ considerando como suficiente a ideia da moldura da norma, mesmo que não haja desenhado métodos para a sua delimitação.

Imperioso mencionar que Kelsen, ao tratar do preenchimento de "lacunas", momento em que o julgador teria uma espécie de poder de legislar, considera a hipótese extremamente remota e que, em casos assim, o juiz poderia tentar se imiscuir em uma eventual vontade do legislador e, dessa forma, decidir.

Afirma, no entanto, que essa teoria das lacunas é uma ficção e que o sancionamento de uma teoria fictícia dessa natureza "tem o efeito desejado de restringir consideravelmente a autorização que o juiz tem de atuar como legislador." 11

Vale a transcrição de texto exarado pelo desembargador alagoano Tutmés Albuquerque nos seguintes termos:

É certo, como sustenta Kelsen, que decidir é um ato de escolha entre alternativas possíveis. Isso não quer dizer ou sugerir que o Estado dê um cheque em branco para o juiz decidir como quiser. É que, não obstante tenha uma margem considerável de poder para construir a sua decisão, todo juiz sabe ou pelo menos intui que há interpretaçóeslimite sobre o sentido e alcance dos textos normativos, a partir das quais tudo o mais não passa de uma tentativa autoritária de fazer prevalecer a vontade pessoal em detrimento dos limites impostos pela legalidade. ${ }^{32}$

É alvissareiro perceber-se que alguns membros do Judiciário têm a sensibilidade de entender os reais propósitos de Kelsen e afastá-lo da discricionariedade e do solipsismo.

28 In Teoria Pura do Direito. Tradução João Baptista Machado. 6.ed. São Paulo: Martins Fontes, 2003 p. 393.

29 Idem, p. 393.

30 FULLER, Lon. L. apud TAVARES, André Ramos. Et al. A Interpretação Jurídica em Hart e kelsen:uma postura (anti) realista. In DIMOULIS, Dimitri. Et al (coord) Teoria do Direito Neoconstitucional - superação ou reconstrução do positivismo juírico? São Paulo: Método, 2008, p. 149.

31 In Teoria Geral do Direito e do Estado. Trad. Luis Carlos Borges. 3.ed. São Paulo: Martins Fontes, 2000, p. 215.

32 Disponível em: <http://www.conjur.com.br/2016-mar-24/tutmes-airan-stf-possa-dar-juizo-aos-nossos-juizes>. Consulta em 31-03-2016. 


\section{Discricionariedade judicial}

Imperioso mencionar, ao se tratar acerca da discricionariedade, a extensa e prodigiosa obra de Georges Abboud sobre o tema. Nela o jurista esclarece que "em regra, a discricionariedade é apresentada como uma área em que a Administraçáo pública decide ou determina algo de forma livre e desvinculada." ${ }^{33}$

Sob esse prisma, usa como referência para sua definição a lição de Ernst Forsthoff que assim a conceitua:

O agir discricionário é conceituado como o âmbito de ação, de decisão e escolha entre várias formas de comportamento, igualmente possíveis. Não se perdendo de vista que, por possível, deve-se sempre ler juridicamente possível. ${ }^{34}$

Depois de transmutada à forma judicial de sua aplicação, a discricionariedade restou extremamente afeta ao positivismo. Dworkin denuncia que os positivistas extraíram seu conceito da linguagem ordinária e que para entendê-lo é preciso colocá-lo de volta em seu habitat, deixando à vontade em um tipo de contexto, qual seja, a tomada de decisóes conforme padróes estabelecidos por uma autoridade. ${ }^{35}$

O renomado jurista estadunidense confere à expressão "poder discricionário" três sentidos: forte; fraco e limitado. Na síntese de Rafael Tomaz de Oliveira a respeito, temos:

O sentido limitado oferece poucos problemas para sua definiçáo. Significa que o poder da autoridade ao qual se atribui poder discricionário determina-se a partir da possibilidade de escolha "entre" duas ou mais alternativas. A esse sentido, Dworkin agrega a distinçấo entre discricionariedade em sentido fraco e em sentido forte, cuja determinação é bem mais complexa. (...) A principal diferença reside no fato de que, em seu sentido forte, a discricionariedade implica incontrolabilidade da decisão segundo um padrão antecipadamente estabelecido. (...) Desse modo, alguém que possua poder discricionário em seu sentido forte pode ser criticado, mas não pode ser considerado desobediente. ${ }^{36}$

Mesmo que analisando a aplicação dos princípios, Rafael Tomaz de Oliveira dispara e acerta também no tema em tela ao cravar sobre a "necessidade de se criar anteparos para a atividade do juiz, para que seja coibida ao máximo a chamada discricionariedade judicial." ${ }^{7}$

Arremata precisamente o mesmo autor dizendo que "a discricionariedade implica poderes normativo-regulatórios para o juiz, o que traz consigo toda a questáo envolvendo a legitimidade da judicatura." 38

No entanto, vale trazer a lume a advertência de Fernando Luiz Vieira acerca do tema, vazada nos seguintes termos:

33 ABBOUD, Georges. Discricionariedade Administrativa e Judicial - O ato administrativo e a decisão judicial. São Paulo: Editora Revista dos Tribunais, 2014, p. 124.

34 Idem, ibidem.

35 In Levando os Direitos a Sério. Tradução Nelson Boeira. 2.ed. são Paulo: Martins Fontes, 2007, p. 50.

36 In Decisáo Judicial e o Conceito de Princípio - A hermenêutica e a (in) determinação do Direito. Porto Alegre: Livraria do Advogado, 2008, p. 28 (nota 3)

37 In Decisáo Judicial e o Conceito de Princípio - A hermenêutica e a (in) determinação do Direito. Porto Alegre: Livraria do Advogado, 2008, p. 65.

38 Idem, p. 65. 
A discricionariedade judicial reflete a maior aporia do juspositivismo. Por um lado, Constituiçôes são formuladas, fazem-se leis, estabelecem-se critérios para resolução dos casos e, por fim, esquece-se de tudo isso e delega-se a decisão à consciência subjetiva do juiz. ${ }^{39}$

Marcelo Neves, por seu turno, assevera que não se deve confundir imprecisão semântica dos textos normativos com discricionariedade, devendo-se encontrar na própria norma, as eventuais alternativas para o órgão responsável pela concretização. ${ }^{40}$

\section{Críticas quanto à relação da "moldura da norma” e a discricionariedade}

É possível, já de antemão, denunciar, como faz Fernando Vieira Luiz, que "a primeira forma de aparição da discricionariedade judicial na prática atual é a filiação ao pensamento de Kelsen." ${ }^{41}$

Necessário alertar, no entanto, que se trata de uma visão reducionista e utilitária do pensamento kelseniano na práxis brasiliera, em que pesem as críticas que se faça a ele.

Analisando mais detidamente a obra de Kelsen, acaba por se tornar leviano atribuir-lhe a possibilidade de concessão de poderes para uso de juízos pessoais (discricionários) ao intérprete. Perscrutando a essência do pensamento Kelseniano, Luis Alberto Warat conclui que ele:

Procurou um critério e um método que lhe permitisse excluir do campo temático das ciências jurídicas as opiniōes, os preconceitos, os juízos de valor, assim como as afirmações ideológicas e as pressuposições metafísicas e políticas que integravam a dogmática jurídica. ${ }^{42}$

As justificativas para o uso da discricionariedade, muita vez, têm base numa ideia de busca por uma suposta justiça, seu uso é sempre com um viés "positivo", "do bem" e "para o bem". Esses tais juízos de "justiça” também são criticados por Kelsen, na percuciente observação de Warat $^{43}$, como dependentes de uma decisão emocional que, do ponto de vista do conhecimento científico, é arbitrária.

Friedrich Muller, responsável por cunhar a expressão pós-positivismo ${ }^{44}$ e seu principal corifeu, é veemente ao criticar a moldura de Kelsen. Para o autor alemão:

39 LUIZ, Fernando Vieira. Teoria da Decisão Judicial: dos paradigmas de Ricardo Lorenzetti à resposta adequada de Lênio Streck. Porto Alegre: Livraria do Advogado, 2013, p.40.

40 NEVES, Marcelo. Entre Hidra e Hércules - Princípios e regras constitucionais. 2. ed. São Paulo: Martins Fontes, 2014, p.13-14.

41 LUIZ, Fernando Vieira. Teoria da Decisão Judicial: dos paradigmas de Ricardo Lorenzetti à resposta adequada de Lênio Streck. Porto Alegre: Livraria do Advogado, 2013, p. 47.

42 WARAT, Luis Alberto; PÊPE, Albano Marcos Bastos. Filosofia do Direito - uma introdução critica. São Paulo: Moderna, 1996, p. 50.

43 WARAT, Luis Alberto; PÊPE, Albano Marcos Bastos. Filosofia do Direito - uma introdução critica. São Paulo: Moderna, 1996, p. 51.

44 Vale a crítica de alguns doutrinadores (por todos, Henrique Garbellini Carnio) de que a melhor tradução para o termo Nach Positivism cunhado por Muller não seria pós-positivismo - o que levaria ao entendimento de um movimento de sucessão do positivismo sobre as mesmas bases - e sim algo como "após o positivismo", o que redundaria em uma nova forma de se pensar o Direito com matrizes e metodologia próprias. 
A norma como ordem não oferece mais que um quadro para uma série de possibilidades decisórias logicamente equivalentes. Cada ato que preenche esse quadro em qualquer sentido logicamente possível, está em conformidade com o direito, ficando eliminada aqui a pergunta pela correção quanto ao conteúdo. ${ }^{45}$

Tal conclusão vai ao encontro daquela formulada por Leonel Severo da Rocha de que, em sendo assim, Kelsen "aceitaria a total irracionalidade da interpretação feita pelos órgáos do Direito, não havendo métodos ou critérios que 'segurem' a interpretaçáo."46

É eloquente a passagem de Kelsen, extraída da obra de lançamento póstumo Teoria Geral das Normas, vazada nos seguintes termos:

Se o juiz está autorizado a decidir os casos sub judice para ele "justos", quer dizer, decidir segundo um princípio que ele tem como justo, então significa que é supérflua a validade de normas jurídicas gerais produzidas por via legislativa ou Costume. ${ }^{47}$

Insta também ser mencionada a crítica elaborada por Dimitri Dimoulis, que enuncia que "a metáfora da moldura perde seu sentido se afirmarmos que pode ser traçada livremente pela autoridade competente." 48

Vale trazer à baila a observação de Simone Goyard-Fabre aduzindo que, mesmo que Kelsen escreva que a Teoria Pura do Direito é a teoria do positivismo jurídico, isso não significa abraçá-lo nem ainda adotar-se "os considerandos ou os objetivos prático-pragmáticos da vulgata positivista." 49

Gabriel Nogueira Dias, ${ }^{50}$ profundo estudioso da obra de Kelsen utiliza, inclusive o termo pseudo-juspositivismo, para diferenciar do projeto juspositivista defendido pelo jurista vienense de outras formas de se entender o positivismo jurídico.

O próprio Kelsen dá pistas de que não se rende a um realismo jurídico nem a uma absoluta indeterminação ou uma incontornável discricionariedade quando afirma que "o juiz não recorre ao Direito em busca de uma resposta à questão do que ele efetivamente fará, mas em busca de uma resposta à questão do que ele deve fazer." ${ }^{51}$ Ou seja, evidencia-se que o direito é, em larga medida, parâmetro da decisão do juiz.

É ele ainda quem assevera que "a norma jurídica inferior possui validade porque foi criada em conformidade com as cláusulas da norma superior". ${ }^{52} \mathrm{E}$ arremata dizendo que:

45 In Teoria Estruturante do Direito. 2.ed. São Paulo: RT, 2009, p. 27.

46 Apud LUIZ, Fernando Vieira. Teoria da Decisáo Judicial: dos paradigmas de Ricardo Lorenzetti à resposta adequada de Lênio Streck. Porto Alegre: Livraria do Advogado, 2013, p. 51.

47 Teoria Geral das Normas. Traduçáo José Florentino Duarte. Porto Alegre: Sergio Antonio Fabris editor: 1986, p. 287.

48 in Positivismo Jurídico: introdução a uma teoria do direito e defesa do pragmatismo jurídico-politico. São Paulo: Método, 2006, p. 211.

49 In Filosofia Crítica e Razão Jurídica. Trad. Maria Ermantina de Almeida Prado Galvão. São Paulo: Martins Fontes, 2006, p. 241.

50 In Positivismo Jurídico e a Teoria Geral do Direito: na obra de Hans Kelsen. São Paulo: Editora revista dos Triunais, 2010, p. 28.

51 In Teoria Geral do Direito e do Estado. Trad. Luis Carlos Borges. 3.ed. São Paulo: Martins Fontes, 2000, p. 244.

52 O Que é Justiça. Trad. Luis Carlos Borges. 3.ed. São Paulo: Martins Fontes, 2001, p. 213. 
Direito estatutário e o Direito consuetudinário são fundamentados na Constituição exatamente como as decisôes dos tribunais, isto é, as normas individuais que os tribunais estabelecem são fundamentadas nos estatutos..$^{53}{ }^{54}$

Simone Goyard-Fabre complementa, comentando a Teoria Pura do direito, que sempre compete a uma norma jurídica:

Conferir a um ato o seu significado de ato de direito (...) Essa norma é sempre "o significado de um ato de vontade"; mas o importante é que ela não possa, enquanto "esquema de interpretação" com função diretriz, ser isolada das outras normas de um sistema jurídico: norma interpretativa, ela própria é criada por meio de atos de direito que, também eles, receberam seu significado jurídico apenas em virtude de outras normas. No direito, o normativo vem do normativo." 55

Ao tratar sobre a irrelevância das circunstâncias individuais do juiz, Kelsen consigna que "a única questão relevante é saber se o juiz aplicará o Direito - tal como descrito pela jurisprudência normativa, ou seja, como um sistema de normas válidas - num caso concreto." 56 Assim, resta ao intérprete autêntico obedecer ao ordenamento jurídico, pois, do ponto de vista da doutrina kelseniana, este é o Direito válido.

Kelsen é claro ao conferir poder a um tribunal para edição de norma individual e não de norma geral, sobretudo em democracia em que há o parlamento, como é o caso brasileiro. Ele não admite a concorrência dos tribunais com o Legislativo, redundando em evidente descentralização da função deste. ${ }^{57}$

O mestre vienense espanca ainda a discricionariedade nos moldes pátrios ao comentar a atribuição de poderes criadores extensos aos Tribunais, quanto a uma ficção de ausência de norma geral ou de uma insatisfatoriedade normativa:

Se ele formulasse esta atribuição de competência de uma maneira teoreticamente acertada, isto é, sem qualquer ficção, deveria preceituar: quando a aplicação da ordem jurídica vigente é, segundo a concepção ético-política do tribunal, insatisfatória no caso sub judice, o tribunal pode decidir o caso segundo a sua livre apreciação. Uma tal formulação conferiria ao tribunal, porém, u poder evidentemente demasiado extenso. $\mathrm{O}$ juiz teria poder para decidir segundo o seu arbítrio sempre que houvesse a aplicação da ordem jurídica vigente como insatisfatória (...) Se a concepção ético-política do juiz toma o lugar da concepção ético-política do legislador, este abdica em favor daquele. ${ }^{58}$

E prossegue quanto a presunçóes interpretativas e se referindo à (descartada) hipótese da ocorrência das lacunas e sua colmatação:

53 Idem, p. 214.

54 Vale transcrever a organização que Kelsen propõe para melhor enquadramento do acima colacionado: "A ordem jurídica de um Estado é, assim, um sistema hierárquico de normas legais. Em forma bastante simplificada, apresenta o seguinte relato: o nível mais baixo é composto de normas individuais criadas pelos órgáos aplicadores de Direito, especialmente os tribunais. Essas normas individuais são dependentes dos estatutos, que são as normas gerais criadas pelo legislador, e das regras do Direito consuetudinário, que formam o nível superior seguinte da ordem jurídica. Esses estatutos e regras de Direito consuetudinário, por sua vez, dependem da constituição, que forma o nível mais elevado da ordem jurídica considerada como sistema de normas positivas. Idem, p. 215-216.

55 In Filosofia Crítica e Razão Jurídica. Trad. Maria Ermantina de Almeida Prado Galvão. São Paulo: Martins Fontes, 2006, p.237.

56 In Teoria Geral do Direito e do Estado. Trad. Luis Carlos Borges. 3.ed. São Paulo: Martins Fontes, 2000, p. 251.

57 In Teoria Pura do Direito. Tradução João Baptista Machado. 6.ed. São Paulo: Martins Fontes, 2003 p.279.

58 In Teoria Pura do Direito. Tradução João Baptista Machado. 6.ed. São Paulo: Martins Fontes, 2003 p.275-276. 
A suposição de um tribunal de que um caso não foi previsto pelo legislador e de que o legislador teria formulado o Direito de diferente modo se tivesse previsto o caso, fundase quase sempre numa presunção não-demonstrável. A intenção do legislador somente é apreensível com suficiente segurança quando adquira expressão no Direito por ele criado. (...) o juiz somente pode se fazer de legislador quando o Direito apresente uma lacuna. Como, porém, o Direito vigente é sempre aplicável, pois não há "lacunas" nesse sentido, esta fórmula, quando se penetre o seu caráter fictício, não opera a pretendida limitação do poder atribuído ao tribunal, mas a auto-anulação da mesma. ${ }^{59}$

Trilhando já um caminho pavimentado pelo pós-positivismo, Eros Grau ${ }^{60}$ faz importante ressalva quanto à metáfora da moldura da norma, significando-a como não a moldura da norma, mas do texto da norma. E não apenas dele, já que concomitantemente seria também uma moldura da realidade.

Eros Grau parece levar em conta a teoria dos dois corpos do rei de Kantorowicz, transmutada para o julgador ao afirmar que:

Assim é o juiz: interpreta o Direito cumprindo o papel que a Constituição lhe atribui. E de modo tal que se transforma em coisa-juiz e passa a ser uma representação para os outros, um modo de ser que não é ele mesmo, mas somente o ser do juiz. (...) enquanto estiver sendo juiz, deve representar o papel de juiz, nos termos da Constituição e da legalidade. ${ }^{61}$

Ensina Lênio Streck que "Kelsen não separou o Direito da moral e, sim, a ciência do Direito da moral." ${ }^{62}$ Essa cisão em Kelsen irá determinar seu conceito de interpretação, também cindida em interpretação como ato de vontade e interpretaçáo como ato de conhecimento. A primeira produz normas no momento de sua aplicação e a segunda proposiçóes. ${ }^{63}$

Para Lênio Streck, ${ }^{64}$ a discricionariedade do intérprete e o decisionismo oriundos da metáfora da 'moldura da norma' de Kelsen são preocupantes, enquanto problema, já que incubado de forma difusa ou até inconsciente no imaginário dos juristas.

Levando em conta desde a traduçâo do termo - bild - e a postura positivista normativista de Kelsen, Streck tenta socorrer para uma melhor interpretação da proposta daquele jurista, afirmando que:

Para Kelsen, o cientista faz um ato de conhecimento, descritivo, não prescritivo; já o aplicador da lei faz um ato de vontade (acrescento [Streck] de poder). Juiz não faz ciência e, sim, política jurídica. (...) Quem aplica a lei, o juiz, não tem nenhum método ou outros critérios que possam assegurar que uma aplicação é melhor que outra ou que uma seja correta e outra não. ${ }^{65}$

59 In Teoria Pura do Direito. Tradução João Baptista Machado. 6.ed. São Paulo: Martins Fontes, 2003 p.276.

60 In Por Que Tenho Medo dos Juizes? A interpretação/aplicação do Direito e dos princípios. 6.ed. São Paulo: Malheiros, 2014, p. 16.

61 Op cit. p. 21.

62 Disponível em: <http://www.conjur.com.br/2014-nov-13/senso-incomum-maldicao-estaria-interpretacaodireito-kelsen>. Acesso em: 01-03-2016.

63 STRECK, Lênio. Verdade e Consenso - Constituiçâo, hermenêutica e teorias discursivas. 5.ed. São Paulo: saraiva, 2014, p. 35.

64 STRECK, Lênio. Verdade e Consenso - Constituição, hermenêutica e teorias discursivas. 5.ed. São Paulo: saraiva, 2014, p. 35.

65 STRECK, Lênio. Verdade e Consenso - Constituição, hermenêutica e teorias discursivas. 5.ed. São Paulo: saraiva, 2014, p. 35 (nota 7$)$ 
No entanto, Streck reconhece que em algum momento o próprio Kelsen se rende aos adversários considerando que a interpretação jurídica é "eivada por subjetivismos provenientes de uma razão prática solipsista." ${ }^{66}$ Mais à frente, o jurista gaúcho assevera que, todavia, Kelsen "náo autoriza o intérprete a escolher o sentido que mais lhe convier, o que seria dar azo à discricionariedade e/ou ao decisionismo. ${ }^{67}$

Earremata consignando que “a 'vontade’ e o 'conhecimento' do intérprete não constituem salvo-conduto para a atribuição arbitrária de sentidos e tampouco para uma atribuição de sentidos arbitrária”. 68

No entanto, forçoso concluir que a discricionariedade judicial "nada mais é do que uma abertura criada no sistema para legitimar, de forma velada, uma arbitrariedade, não mais cometida pelo administrador, mas pelo Judiciário". ${ }^{69}$

Também imperioso se referir, dada, sobretudo, a sua expansão na teoria jurídica pátria embora neste estudo contrariada — bem como a aproximação com a metáfora da moldura ora estudada e sua utilização também como álibi, a ideia de Herbert Hart acerca da discricionariedade e da criação do Direito pelos tribunais. Consigna o ilustrado positivista que:

Nos casos mais importantes, há sempre uma escolha. O juiz tem de escolher entre sentidos alternativos a dar às palavras de uma lei ou entre interpretaçóes conflituantes do que um precedente "significa". As regras jurídicas podem ter um núcleo central de sentido indiscutível (...) contudo, todas as regras têm uma penumbra de incerteza em que o juiz tem de escolher entre alternativas. ${ }^{70}$

É nessa "zona de penumbra” que se desenvolverá a discricionariedade judicial, terreno em que o juiz materializará suas "escolhas" fundantes da decisão a ser proferida.

No entanto, ao final de sua obra $O$ conceito de Direito, Hart, em célebre diálogo com Dworkin, faz uma espécie de reparo ou de limitação da discricionariedade, chamando a atenção para o fato de que:

Os poderes de criação que eu atribuo aos juízes, para resolverem os casos parcialmente deixados por regular pelo direito, sejam diferentes de um órgão legislativo: não só os poderes do juiz são objectos de muitos constrangimentos que estreitam a sua escolha, de que um órgão legislativo pode estar consideravelmente liberto, mas, uma vez que os poderes do juiz são exercidos apenas para ele se libertar de casos concretos que urge resolver, ele não pode usá-los para introduzir reformas de larga escala ou novos códigos. ${ }^{71}$

Referida "limitação" não afasta, evidentemente, a ideia de discricionariedade judicial, tampouco da existência de uma "área” em que o intérprete exercerá suas "escolhas”. Prova disso é o que se segue no mesmo parágrafo da citada obra: "Apesar disso, haverá pontos em que o direito

66 STRECK, Lênio. Verdade e Consenso - Constituição, hermenêutica e teorias discursivas. 5.ed. São Paulo: saraiva, 2014, p. 36.

67 STRECK, Lênio. Verdade e Consenso - Constituição, hermenêutica e teorias discursivas. 5.ed. São Paulo: saraiva, 2014, p. 49.

68 STRECK, Lênio. Verdade e Consenso - Constituição, hermenêutica e teorias discursivas. 5.ed. São Paulo: saraiva, 2014, p. 49

69 Id., ibid., p. 52.

70 In O Conceito de Direito. Tradução A. Ribeiro Mendes. 4.ed. Lisboa: Fundação Calouste Gulbenkian. 2005, p. 17.

71 Op cit, p. 336. 
existente não consegue ditar qualquer decisão que seja correta e, para decidir os casos em que tal ocorra, o juiz deve exercer os seus poderes de criaçáo do direito." ${ }^{72}$

Para Eros Grau, analisando mais de uma obra de Kelsen, fica claro que o autor austríaco mostra a "impossibilidade lógica de se encontrar distinções qualitativas entre a atividade do juiz (ao interpretar) e a atividade do administrador, na prática da falsa discricionariedade", ${ }^{73}$ concluindo que a divisão dos atos jurídicos em livres (discricionários) e vinculados carece de sentido. Grau afirma categoricamente que a Kelsen "não escapa o sentido perverso da discricionariedade". ${ }^{74}$

Cumpre ainda trazer-se a advertência de Friedrich Müller a esse respeito, nos seguintes termos: "no Estado Democrático de Direito a precisão máxima possível e a racionalidade igualitária em termos ótimos do trabalho jurídico não estão abandonados a uma opção de confiança”. ${ }^{75}$

Por derradeiro, insta compartilhar-se de precisa compilação realizada por Gabriel Nogueira Dias de críticas remetidas por Kelsen à ciência do Direito, vazada nos seguintes termos:

Segundo Kelsen, a ciência do direito, marcada por "sincretismo", "conceitos híbridos" e "fantasmas", degenerou-se numa "disciplina pobre". Ela se apresenta como uma "barafunda científica" que não teria condiçôes de se livrar de suas "contradiçôes internas"76

Tais críticas são de 1911 e dirigiam-se à ciência jurídica do passado e daquele presente. Mal poderia imaginar que suas colocaçôes, infelizmente, se tornariam quase que permanentes e, como visto neste estudo, voltando-se contra seus próprios escritos.

\section{Casos concretos do uso indevido da "moldura da norma" pelos tribunais brasileiros}

Não é difícil encontrar em decisôes de nossos tribunais referências a Kelsen, evidentemente. Como nos diz Mario Losano "na ciência jurídica do século XX, o pensamento mais rigoroso é o do positivismo jurídico, e sua formulação mais completa é a Teoria Pura do Direito."77

Dessa importância corrobora Arthur Kauffmann quando afirma que " a teoria pura do direito é a mais importante expressão do positivismo-normativista ou lógico-normativo. Kelsen apostrofou-a como "a" teoria do positivismo jurídico." 78

Muitas das vezes, os ensinamentos de Kelsen são referidos com acerto. Mas também são comuns em decisóes a deturpação de sua doutrina, o que vem sendo objeto do presente estudo. Passa-se a colacionar alguns julgados e que ela foi utilizada como verdadeiro álibi para decisóes solipsistas.

72 Idem, p. 336.

73 In O Direito Posto e o Direito Pressuposto. 6.ed. Sáo Paulo: Malheiros, 2005, p. 213.

74 Idem, p. 213.

75 O Novo Paradigma do Direito: Introdução à teoria e metódica estrturantes. 3.ed. São Paulo: Revista dos Tribunais, 2013, p. 13.

76 In Positivismo Jurídico e a Teoria Geral do Direito: na obra de Hans Kelsen. São Paulo: Editora revista dos Triunais, 2010, p. 141.

77 In Sistema e Estrutura no Direito. Vol 2 o século XX. Tradução Luca Lamberti. São Paulo: Martins Fontes, 2010, p. 25.

78 KAUfMANN, Arthur. Filosofia do Direito. 5. ed. Traduçáo António Ulisses Cortes. Lisboa: Calouste Gulbenkian, 2014, p.21. 
Do Superior Tribunal de Justiça traz-se uma decisão em agravo de instrumento em que o ministro relator faz tabula rasa da lição de Kelsen sobre a moldura e a adéqua sob medida ao que pretende justificar como fundamentação:

STJ. AgRg no AGRAVO DE INSTRUMENTO No 1.141 .872 - RS (2009/0085592-

5). RELATOR : MINISTRO ARNALDO ESTEVES LIMA ${ }^{79}$

\section{VOTO}

MINISTRO ARNALDO ESTEVES LIMA (Relator):

Pugna o agravante, neste regimental, pela reforma da decisão que negou provimento ao agravo de instrumento, afirmando que o recurso especial interposto merece prosseguir. Sustenta, para tanto, a presença de nulidade ocorrida no Júri, consistente na instalação da sessão de julgamento com apenas 14 jurados, assim como a incompatibilidade entre sua condenação e a prova dos autos, na medida em que teria agido em legítima defesa.

O pleito não deve prosperar.

Na liçáo de Kelsen, o ato interpretativo é misto intelectual e volitivo. intelectualmente verifica-se as possibilidade interpretativas. volitivamente, escolhe-se a mais adequada no caso concreto.

Cabe ao intérprete, dentro da moldura da norma, escolher uma de suas possibilidades de aplicaçáo, que a meu ver deve ser harmônica com o cogente artigo $5^{\circ} \mathrm{da}$ LICC. Inseparáveis bem comum, fins sociais e justiça, a virtude maior, tenho por evidente.

Sob esse prisma, razoável interpretar-se o art. 572 do CPP como aplicável apenas às nulidades nele expressamente mencionadas. quanto às demais, deve ser aplicado o título das nulidades no seu todo. (grifos do autor)

79 EMENTA PROCESSO PENAL. AGRAVO REGIMENTAL NO AGRAVO DE INSTRUMENTO. HOMICÍDIO. JÚRI. NULIDADE. NAO-ARGUIÇAO EM MOMENTO OPORTUNO. AUSÊNCIA DE DEMONSTRAÇAO DE PREJUÍZO. CONDENAÇAO CONTRÁRIA À PROVA DOS AUTOS. REEXAME DO CONTEXTO FÁTICO. IMPOSSIBILIDADE. SÚMULA 7/STJ. AGRAVO IMPROVIDO.

1. No processo penal pátrio, no cenário das nulidades, vigora o princípio geral de que somente se proclama a nulidade de um ato processual quando há a efetiva demonstração de prejuízo, nos termos do que dispóe o art. 563 do Código de Processo Penal e a Súmula 523/STF. 2. Não houve manifestação contrária à pretensa nulidade no momento, tendo a defesa concordado expressamente com a instalação da sessão de julgamento com 14 jurados. Ademais, náo foi demonstrado prejuízo advindo da alegada irregularidade para a defesa. 3. Impossibilidade de exame da alegação de decisão contrária à prova dos autos, por exigir revolvimento do contexto fático-probatório, vedado pela Súmula 7/STJ. 4. Agravo regimental improvido. RELATÓRIO: MINISTRO ARNALDO ESTEVES LIMA: Trata-se de agravo regimental interposto por LEO LUIZ SABADIN contra decisão de fls. 119/121, a qual negou provimento a agravo de instrumento manejado em face de decisão que inadmitiu o recurso especial interposto contra acórdão do Tribunal de Justiça do Estado do Rio Grande do Sul que, em sede de apelação, manteve sentença que o condenou à pena de 14 anos de reclusão pela prática do delito inscrito no art. 121, 2 o , IV, do Código Penal. Pugna o agravante, inicialmente, pelo reconhecimento da nulidade do Júri que o condenou, porquanto instalada a sessão de julgamento com a presença de apenas 14 jurados. Sustenta, de outra parte, que a sentença é contrária à prova dos autos, porquanto teria agido em legítima defesa. Requer, assim, o provimento do regimental a fim de que seja acolhido o agravo de instrumento e, por consequência, seja dado seguimento ao recurso especial. É o relatório. 
Nota-se que tamanha "elasticidade" indevidamente atribuída a Kelsen, faz com que o julgador possa alcançar qualquer resultado e sua decisão, se ter, com isso, que se ater à devida fundamentação ou até mesmo à adequação constitucional.

Gabriel Nogueira Dias é categórico ao afirmar que "em momento algum de sua vida dedicada à ciência do direito ele aceitou que o surgimento de uma norma pudesse ocorrer sem o ato de vontade primário." ${ }^{80}$ Fica claro, para quem quiser ver, é claro, que Kelsen condena o decisionismo e o solipsismo.

O Tribunal Superior do Trabalho também é pródigo no uso incorreto (solipsista) da moldura de Kelsen. Difunde-se, inclusive, entre as turmas daquele órgão. E usam, como apoio doutrinário, liçôes de um magistrado também bastante inclinado à discricionariedade e, via de consequência, ao solipsismo:

TST. (Ac. $3^{a}$ Turma) Agravo em Agravo de Instrumento em Recurso de Revista no TSTAg-AIRR-34500-28.2009.5.15.0069

A C Ó R D Ã O

\section{(...)}

Cabível invocar, ainda, o método teleológico de interpretação jurídica para enfrentar esse tormentoso assunto, valendo relembrar o escólio de Vicente Ráo para quem:”o sentido literal da lei deve ceder o passo a sentido outro, ditado pela necessidade de se satisfazerem os interesses contidos no caso concreto"(O Direito e a Vida dos Direitos). Dessa lição extrai-se que cabe ao Juiz, no momento da aplicação da regra jurídica, um exercício criativo - sem as limitaçôes do texto legal e desvinculada da busca da vontade do legislador impressa na norma - e voltado às realidades sociais colocadas em jogo no caso" sub judice ", porém adstrito aos princípios ético-jurídicos previstos na ordem jurídica. Nesse mesmo sentido, pede-se vênia para transcrever alguns doutrinadores citados no excelente estudo" Ativismo Judicial ", do ilustre Desembargador Luiz Roberto Nunes, publicado na Revista do E.TRT da 15a Região, n. ${ }^{\circ}$ 38, páginas 62 e 67

\section{(...)}

80 Positivismo Jurídico e a Teoria Geral do Direito: na obra de Hans Kelsen. São Paulo: Editora revista dos Triunais, 2010, p. 143 (nota 41).

81 AGRAVO EM AGRAVO DE INSTRUMENTO EM RECURSO DE REVISTA - DESCABIMENTO. DECISÃO IMPUGNADA EM CONFORMIDADE COM A JURISPRUDÊNCIA UNIFORME DO TRIBUNAL SUPERIOR DO TRABALHO. O "caput" do artigo 557 do CPC é expresso ao dispor que "o relator negará seguimento a recurso manifestamente inadmissível, improcedente, prejudicado ou em confronto com súmula ou com jurisprudência dominante do respectivo tribunal, do Supremo Tribunal Federal, ou de Tribunal Superior." Na esfera trabalhista, a medida encontra eco no $\$ 5^{\circ}$ do artigo 896 da CLT, segundo o qual "estando a decisão recorrida em consonância com enunciado da Súmula da Jurisprudência do Tribunal Superior do Trabalho, poderá o Ministro Relator, indicando-o, negar seguimento ao Recurso de Revista, aos Embargos, ou ao Agravo de Instrumento." Não merece reparos, portanto, a decisão agravada, porquanto proferida em conformidade com a Súmula 331, V, do TST. Agravo conhecido e desprovido. Vistos, relatados e discutidos estes autos de Agravo em Agravo de Instrumento em Recurso de Revista no TST-AgAIRR-34500-28.2009.5.15.0069, em que é Agravante INSTITUTO NACIONAL DO SEGURO SOCIAL - INSS e Agravadas LURDES DOS SANTOS PONCIANO e PRELYMPE PRESTADORA DE SERVIÇOS LTDA. Por meio da decisão monocrática ora atacada, foi denegado seguimento ao agravo de instrumento, com base nos arts. $896, \$ 5^{\circ}$, da CLT e 557, caput, do CPC, em razão de o acórdão regional estar em conformidade com a Súmula 331, V, do TST. O segundo reclamado interpóe agravo, sustentando, em resumo, que o recurso oferece condiçốes de admissibilidade. É o relatório. 
O próprio Kelsen não adota tese tão radical, mas ao contrário afirma categoricamente que além da interpretação ser autêntica, o aplicador tem liberdade para enquadrar o caso concreto dentro da moldura da norma jurídica:"a interpretação feita pelo aplicador do Direito é sempre autêntica. Ela cria Direito

$(\ldots)$

A produção do ato jurídico dentro da moldura da norma jurídica aplicável é livre, isto é, realiza-se segundo a livre apreciação do órgáo chamado a produzir o ato...

Notável o esforço olímpico para que a teoria da moldura se encaixe perfeitamente nas convicçóes pessoais do julgador. Valem ser citados ainda, com o mesmo teor, os seguintes julgados do TST: AgR-AIRR-1124-73.2010.5.15.0018. (J. 12/03/2014), AIRR-10670091.2009.5.15.0082 (J. 12/06/2013), AIRR-609-08.2011.5.15.0146. (J. 29/08/2013 4a Turma) e AIRR-609-08.2011.5.15.0146. J. 29/08/2013 4a Turma. $^{82}$

\section{Consideraçóes finais}

Conforme se objetivou no presente estudo, cuidou-se de analisar o mau entendimento acerca da metáfora da "moldura da norma" de Hans Kelsen. Tal verificação restou demonstrada.

Lamentável que existam em nossa prática jurídica, sobretudo na dos tribunais, o uso indiscriminado, inconsequente ou utilitarista de institutos, técnicas e doutrinas. A metáfora da moldura da norma de Kelsen faz parte desta lista.

Como visto, ou por não se entender devidamente a questão ou por fazer dela tabula rasa a servir ao solipsismo ou como um álibi para se atingir um resultado desejado previamente pelo julgador, a moldura de Kelsen acaba por tornar-se "infinita" em nome de uma incontornável discricionariedade. Beira-se o realismo jurídico, aliás.

Kelsen acabou virando álibi para o decisionismo. Não que seja totalmente correto afastar absolutamente tal prática de seus ensinamentos, mas daí a associar aquele que mais quis evitar a contaminação do direito por fatores externos ao uso indiscriminado da discricionariedade também já seria demais.

Fica cada vez mais clara a falta de preparo intelectual e/ou doutrinário (ou seu mau uso) em nome de interesses e convicçóes pessoais em evidente deturpação de seus ensinamentos.

82 AGRAVO DE INSTRUMENTO. RECURSO DE REVISTA. 1. CONTRATO DE PRESTAÇÃO DE SERVIÇOS. TERCEIRIZAÇÁOO. VIGILANTE. RESPONSABILIDADE SUBSIDIÁRIA DO TOMADOR DE SERVIÇOS. ENTE PÚBLICO. 2. ABRANGÊNCIA DA CONDENAÇÃO. MULTAS. 3. JUROS DE MORA. Náo demonstrada nenhuma das hipóteses de cabimento do recurso de revista previstas no art. 896 da CLT. Fundamentos da decisão denegatória não desconstituídos. Agravo de instrumento a que se nega provimento. Vistos, relatados e discutidos estes autos de Agravo de Instrumento em Recurso de Revista no TST-AIRR-609-08.2011.5.15.0146, em que é Agravante CENTRO ESTADUAL DE EDUCAÇÃO TECNOLÓGICA "PAULA SOUZA" - CEEETEPS e são Agravados WAGNER MOREIRA e BUZATI \& BUZATI SEGURANÇA LTDA. O Vice-Presidente do Tribunal Regional do Trabalho da Décima Quinta Regiāo denegou seguimento ao recurso de revista interposto pelo Reclamado, o que ensejou a interposição do presente agravo de instrumento. O Agravado (WAGNER MOREIRA) apresentou contraminuta ao agravo de instrumento e contrarrazóes ao recurso de revista.

Os autos foram remetidos ao Ministério Público do Trabalho. É o relatório. 


\section{Referências}

ABBOUD, Georges; CARNIO, Henrique Garbellini; OLIVEIRA, Rafael Tomaz de. Introdução à Teoria e à filosofia do Direito. São Paulo: Revista dos Tribunais, 2013.

ABBOUD, Georges. Discricionariedade Administrativa e Judicial - $\mathrm{O}$ ato administrativo e a decisão judicial. São Paulo: Revista dos Tribunais, 2014.

CATTONI DE OLIVEIRA, Marcelo. Interpretação Como Ato de Conhecimento e Interpretação como Ato de Vontade: a tese kelseniana da interpretação autêntica. Jurisdição e Hermenêutica Constitucional. CATTONI DE OLIVEIRA, Marcelo (org.). Belo Horizonte: Mandamentos, 2004 .

DIAS, Gabriel Nogueira. Positivismo Jurídico e a Teoria Geral do Direito: na obra de Hans Kelsen. São Paulo: Revista dos Tribunais, 2010.

DWORKIN, Ronald. Levando os Direitos a Sério. Tradução Nelson Boeira. 2. ed. são Paulo: Martins Fontes, 2007.

FACCINI NETO, Orlando. Elementos de Uma Teoria da Decisáo Judicial-Hermenêutica, Constituição e respostas corretas em Direito. Porto Alegre, 2011

GARBELLINI CARNIO, Henrique. O Pensamento Kelseniano e o Conceito de Vontade no direito Privado. Revista de Direito Privado. Vol 51, jul./set. 2012. RT online. Consulta em: 1603-16.

GOUVEIA, Samuel Moreira. Kelsen e a Interpretação Humpty Dumpty (no prelo).

GOYARD-FABRE, Simone. Filosofia Crítica e Razão Jurídica. Tradução Maria Ermantina de Almeida Prado Galvão. São Paulo: Martins Fontes, 2006.

GRAU, Eros Roberto. O Direito Posto e o Direito Pressuposto. 6. ed. São Paulo: Malheiros, 2005.

GRAU, Eros Roberto. Por Que Tenho Medo Dos Juizes- a interpretação/aplicação do direito e os princípios. 6. ed. São Paulo: Malheiros, 2014.

GUERRA FILHO, Willis Santiago; GARBELLINI CARNIO, Henrique. Teoria da Ciência Jurídica. 2. ed. São Paulo: Saraiva, 2009

HART, Herbert L. A. O Conceito de Direito. Tradução A. Ribeiro Mendes. 5. ed. Lisboa: Calouste Gulbenkian, 2007.

KAUFMANN, Arthur. Filosofia do Direito. 5. ed. Tradução António Ulisses Cortes. Lisboa: Calouste Gulbenkian, 2014.

KELSEN, Hans. Teoria Geral das Normas. Tradução José Florentino Duarte. Porto Alegre: Sergio Antonio Fabris, 1986. 
KELSEN, Hans. Teoria Geral do Direito e do Estado. Trad. Luis Carlos Borges. 3. ed. Sáo Paulo: Martins Fontes, 2000.

KELSEN, Hans. O Que é Justiça. Tradução Luis Carlos Borges. 3. ed. São Paulo: Martins Fontes, 2001.

KELSEN, Hans. Teoria Pura do Direito. Tradução João Baptista Machado. 6. ed. São Paulo: Martins Fontes, 2003

LOSANO, Mario. Sistema e Estrutura no Direito. Vol 2: O Século XX. Tradução Luca Lamberti. São Paulo: Martins Fontes, 2010.

LUIZ, Fernando Vieira. Teoria da Decisáo Judicial: dos paradigmas de Ricardo Lorenzetti à resposta adequada de Lênio Streck. Porto Alegre: Livraria do Advogado, 2013.

MAGALHÃES, Juliana Neuenschwander. Sobre a Interpretação Jurídica. Revista de Direito Comparado. Vol 3. Belo Horizonte: Faculdade de Direito da UFMG, 1999.

MÜLLER, Friedrich. Teoria Estruturante do Direito. 2. ed. São Paulo: RT, 2009.

MÜLLER, Friedrich. O Novo Paradigma do Direito: Introdução à teoria e metódica estruturantes. 3. ed. São Paulo: Revista dos Tribunais, 2013.

NEVES, Marcelo. Entre Hidra e Hércules - Princípios e regras constitucionais. 2. ed. São Paulo: Martins Fontes, 2014.

OLIVEIRA, Rafael Tomaz de. Decisáo Judicial e o Conceito de Princípio - a hermenêutica e a (in)determinação do direito. Porto Alegre: Livraria do Advogado, 2008.

STRECK, Lênio. Verdade e Consenso - Constituição, hermenêutica e teorias discursivas. 5. ed. São Paulo: Saraiva, 2014.

TAVARES, André Ramos et al. A Interpretação Jurídica em Hart e kelsen:uma postura (anti) realista. In: DIMOULIS, Dimitri. Et al (coord) Teoria do Direito Neoconstitucional-superação ou reconstrução do positivismo juírico? São Paulo: Método, 2008.

TAVARES, André Ramos et al. Disponível em: <http://www.conjur.com.br/2014-nov-13/ senso-incomum-maldicao-estaria-interpretacao-direito-kelsen>. Acesso em: 01 mar. 2016.

WARAT, Luis Alberto; PÊPE, Albano Marcos Bastos. Filosofia do Direito - uma introdução critica. São Paulo: Moderna, 1996. 